\title{
Predictor Variables of Childbearing Motivations in Brazilian Women and Men
}

\author{
Giuliana Violeta Vasquez Varas ${ }^{1}$ \\ Juliane Callegaro Borsa ${ }^{1}$
}

\begin{abstract}
This study aimed to analyze the relationships between positive (PCM), negative (NCM) childbearing motivations and psychological, sociodemographic, family of origin and partner relationship variables in a sample of 1969 Brazilians (83.6\% female), aged 18 to 50 years $(M=29.27 ; S D=5.97)$. Spearman correlations, Mann-Whitney and Kruskal Wallis U-tests, and multiple regressions were performed. The results of the correlations and multiple regressions verified the relationship between both motivations and the various variables postulated. It was also verified that religiosity was the variable with greater predictive power for PCM and having or not having children was the variable with greater predictive power for NCM. In the group difference analysis, significant differences were found for PCM according to occupation, type of relationship, and presence/absence of a partner. As for the NCM, significant differences were found according to sex.
\end{abstract}

Keywords: motivation, Brazil, conception, parenting

\section{Variáveis Preditoras das Motivações para a Parentalidade em uma Amostra Brasileira}

\begin{abstract}
Resumo: O presente estudo teve como objetivo analisar as relações entre as motivações para a parentalidade positiva (MPP), negativa (MPN) e variáveis psicológicas, sociodemográficas, relacionadas à família de origem e de relacionamento com o parceiro em uma amostra de 1969 brasileiros (83.6\% mulheres), com idades entre 18 e 50 anos $(M=29.27 ; D P=5.97)$. Foram realizados correlações de Spearman, testes de $U$ Mann-Whitney e Kruskal Wallis e regressões múltiplas. Os resultados das correlações e regressões múltiplas verificaram a relação entre ambas as motivações e as diversas variáveis postuladas. Também verificou-se que a religiosidade foi a variável com maior poder preditivo para a MPP e ter ou não ter filhos foi a variável com maior poder preditivo para a MPN. Na análise de diferença de grupos foram encontradas diferenças significativas da MPP seguwndo ocupação, tipo de relacionamento e presença/ausência de parceiro. Já para as MPN, encontraram-se diferenças significativas segundo sexo.
\end{abstract}

Palavras-chave: motivação, Brasil, concepção, parentalidade

\section{Variables Preditoras de las Motivaciones para la Parentalidad en una Muestra Brasilera}

\begin{abstract}
Resumen: El presente estudio tuvo como objetivo analizar las relaciones entre las motivaciones para la parentalidad positiva (MPP) y negativa (MPN) y variables psicológicas, sociodemográficas, relacionadas con la familia de origen y la relación con la pareja en una muestra de 1969 brasileños ( $83,6 \%$ mujeres), con edades entre 18 y 50 años $(M=29,27 ; D E=5,97)$. Se realizaron correlaciones de Spearman, pruebas de U Mann-Whitney y Kruskal Wallis y regresiones múltiples. Los resultados verificaron la relación entre ambas motivaciones y las diversas variables postuladas. También se encontró que la religiosidad fue la variable con mayor poder predictivo para MPP y tener o no tener hijos fue la variable con mayor poder predictivo para MPN. En el análisis de diferencias de grupos se encontraron diferencias significativas del MPP según ocupación, tipo de relación y presencia / ausencia de pareja. Para MNP se encontraron diferencias significativas según el sexo.
\end{abstract}

Palabras clave: motivación, Brasil, concepción, parentalidad

\footnotetext{
${ }^{1}$ Pontificia Universidade Católica do Rio de Janeiro, Rio de Janeiro-RJ, Brazil Support: Article derived from the first author's doctoral thesis under the supervision of the second author, defended in 2021, in the Postgraduate Program in Psychology at Pontifícia Universidade Católica de Rio de Janeiro. Financial support from the CAPES-PEC-PG program (Protocol No.: 88881.130997/2016-01)

Correspondence address: Giuliana Violeta Vasquez Varas. Rua Voluntários da Pátria, 46, Rio de Janeiro-RJ, Brazil. CEP 22.270-010. E-mail: giuli_vv700@hotmail.com
}

The reduction in fertility rates, a process known as the fertility transition, is occurring in all countries. Between 1950 and 1965, the world's total fertility rate (TFR) was around five children per woman, and has halved since 2015 (Fundo de População das Nações Unidas [UNFPA], 2018). Rios-Neto, Miranda-Ribeiro and Miranda-Ribeiro (2018) identified that the most important factor in Brazil's fertility decline was the spread of conscious fertility regulation, 
through the use of contraceptive methods and abortion. For Martine (1996), abortion was the main method used in the 1960s and early 1970s, due to misinformation about the use of contraceptive methods. After this period, with greater dissemination and guidance on methods, sterilization and the pill gained an important space in the regulation of fecundity of Brazilian women (Caetano, Martins, \& Motta, 2016).

With the decrease in the number of children per woman in Brazil, the base of the population pyramid was reduced and the scenario pointed to progressive aging. This transition was very similar to that observed throughout Latin America until 1990, but the decline accelerated in the 2000s, reaching an average of 1.7 children per woman between 2010 and 2015 (Miranda-Ribeiro, Garcia, \& Faria, 2019).

The changes in reproductive behavior registered in Brazil happened in a general and unrestricted way and was associated with economic development indicators, the strengthening of public institutions and changes in gender relations (Smeha \& Calvano, 2009). Inequalities in income and education directly impact fertility rates (UNFPA, 2018). In 2015, for example, despite Brazil having reached TFR below the population replacement level, this rate in some groups still indicated three children per woman, being in communities with less than nine years of schooling or in households with up to one minimum wage of household income per capita (UNFPA, 2018).

Besides the statistical data, which provide an overview of the current situation of fertility in Brazil, its evolution, reflections on the choice of having or not having children and the analysis of the processes that permeate this decision have become increasingly important for the understanding and prediction of reproductive behavior (Miller, 1994). Information about what motivates people to have children is projected as useful knowledge for guidance in the fields of sexual and reproductive health (Tavares, 2016), meeting the needs of different populations by considering their cultural specificities. Unfortunately, Latin American studies on this theme are scarce, as verified in the systematic review developed by Varas and Borsa (2019). Another finding was that the most commonly used model in research on childbearing motivations $(\mathrm{CM})$ and on reproductive decision-making was the multidimensional Traits-Desires-Intentions-Behavior model, also called the T-D-I-B model, developed by researcher Warrem Miller (Miller, 1995). According to Miller, CM refers to the way people think, feel, and behave about childbearing, which drives the action of having or not having children (Miller \& Pasta, 1993). They can be divided into positive childbearing motivations (PCM), characterized by the drive to have children, and negative motivations (NCM), characterized by the opposite direction of this drive. According to Miller (1992), CM have biological bases that provide mechanisms for responding with affection and care to infants and children while being shaped by experiences during childhood, adolescence, and adulthood and influenced by basic personality traits.

Regarding childhood experiences, Miller mentioned that loving and positive family experiences, the transmission of a family-centered value system, and identification with parental roles through modeling learning would help strengthen PCM. During adolescence, caring for younger siblings or other childhood caregiving experiences would impact PM, depending on the perceived pleasure or displeasure of this experience, and different degrees of academic success would reinforce or extinguish childbearing-related interests. In the adult period the educational level and demanding work activities would expand the individual's outlook beyond the family and community of origin and promote competitive activities to parenting; while stable relationships, attendance at religious activities, and continuous positive relationships with the family of origin would strengthen the development of PCM. Finally, the author proposes that people with nurturing and affiliative personality traits could develop strong PCM during childhood, adolescence, and adulthood, while people who tend to be autonomous would have relatively weak PCM development (Miller, 1992).

Considering Brazil as a large country in extension and inequalities, it becomes fundamental to analyze the different socioeconomic, individual and relational nuances that impact TFR and autonomy in reproductive decisions. That said, based on the antecedents of CM proposed by Miller (1994) and Miller, Severy and Pasta (2004) and on studies conducted around the world on variables that influence CM (Alexander, Perrin, Jennings, Ellen, \& Trent, 2019; Ghazanfarpour et al., 2018; Irani \& Khadivzadeh, 2019; Mynarska \& Rytel, 2020; Varas \& Borsa, 2019), This study aimed to analyze the relationships between the motivations for positive childbearing (PCM), negative childbearing (NCM) and psychological, sociodemographic, family of origin and partner relationship variables in a Brazilian sample. The following specific objectives were pursued:

(1) To assess the existence of correlations between CM and variables: sociodemographic (i.e., age, education, and income); childhood-related (i.e., number of siblings, birth order, and family support), personal characteristics (i.e., positivity, personality, and religiosity), and partner relationship (i.e., dyadic consensus).

(2) To determine whether the levels of PCM and NCM vary according to the variables: sex, occupation, presence/ absence of partner, marital status, sibling care, and having or not having children.

(3) Determine the predictive power over $\mathrm{CM}$ of the variables mentioned in objective 1 .

\section{Participants}

\section{Method}

The sample of the present study was composed of 1985 Brazilians, who lived in 26 states and the Federal District. The majority lived in Rio de Janeiro $(n=716,36.4 \%)$ and São Paulo $(n=425,21.6 \%)$. Participants' ages ranged from 18 to 68 years $(M=29.5 ; S D=6.5)$. Most of the sample was composed of female participants $(n=1659,86.6 \%)$, who, at the time of the survey, were in a relationship $(n=1684$, $84.8 \%)$, working ( $n=1404,70.7 \%)$, and had no children 
( $n=1780,89.7 \%)$. In addition, they stated that they were not responsible for the care of younger siblings during childhood or adolescence ( $n=1144,57.6 \%$ ). Among the 1,684 participants who reported being in a relationship, $1684(84.8 \%)$ reported that the length of the relationship was longer than six months, and the most frequently mentioned relationship categories were: "dating" ( $n=667,39.6 \%)$ and "marriage" ( $n=646,38.4 \%)$.

The most frequently mentioned education levels were: complete graduate school $(n=888,44.7 \%)$ and incomplete college education ( $n=430,21.7 \%$ ). About income level, the most reported options were: between three and five minimum wages $(n=611,30.8 \%)$ and above ten minimum wages $(n=479,24.1 \%)$. Finally, regarding birth order, the participants mostly reported being the second $(n=685,32.5 \%)$ and above the fourth $(n=182,27.4 \%)$ child born. The sample was defined by convenience (i.e., non-probability) and the sample size was established based on recommendations in the psychometric literature to enable the feasibility of the analyses (Field, 2017).

\section{Instruments}

Sociodemographic questionnaire. Instrument developed for this research, aimed at collecting socio-demographic and family information, such as biological sex, age, place of residence, income, education, occupation, marital status, among others.

Childbearing Motivation Questionnaire (CBQ) (Miller, 1995). Instrument composed of 47 items divided into two independent scales: Positive Childbearing Motivation (PCM) and Negative Childbearing Motivation (NCM). The PCM scale consisting of 27 items provides an overall PCM score in five categories, which describe positive aspects of having children: (1) pleasures of pregnancy, birth, and childhood, (2) traditional childbearing, (3) satisfaction of raising a child, (4) feeling needed and connected, and (5) instrumental values. The NCM scale consists of 20 items that provides an overall NCM score in four categories, which specify negative aspects of childbearing: (1) discomforts during pregnancy and childbirth, (2) parental fears and concerns, (3) negative aspects of childcare, and (4) parental stress. A 4-point Likerttype scale $(4=$ very much, $3=$ moderate, $2=$ little, $1=$ not at all) is used for this purpose. The process of translation and adaptation of the CBQ for Brazil was performed by Varas and Borsa (2019). The evaluation of internal consistency was performed by calculating the Omega coefficient $\omega$ (McDonald, 1999), and the following results were found: PCM scale $(\omega=.96)$ and NCM scale $(\omega=.92)$.

Dyadic Consensus Scale (DCS) (Spanier, 1976, adapted by Hernández, 2008). Instrument composed of 13 items that evaluate the perception of agreement with the partner on basic issues in the relationship. The scale presented an Omega coefficient $\omega$ (McDonald, 1999) of .89.

Positivity scale (PS) (Caprara et al., 2012, adapted by Borsa, Damásio, Souza, Koller, \& Caprara, 2013). An eightitem instrument that explores the respondent's positive opinion about himself/herself and the future. The scale presented an Omega coefficient $\omega$ (McDonald, 1999) of .86.
Questionnaire on experiences of religiosity (QER). Instrument developed for this study based on questions used in Miller and Pasta's research (1995). It is composed of six items that question the individual's participation in religious practices and the evaluation of religious precepts in daily life choices. The scale presented an Omega coefficient $\omega$ (McDonald, 1999) of.89.

Family Support Perception Inventory (FSPI) (Baptista, 2005). Instrument composed of 42 items that assess three dimensions of family support: (1) affectiveconsistent (AC) composed of 21 items, which involve issues of respect of the expression of affection among members; (2) family adaptation (FA) composed of 13 items that score in an inverted manner proving the absence of adaptation in the group and questioning negative feelings towards the family; (3) autonomy (A), composed of eight items that evaluate the relationships of trust, freedom and privacy among members. The FSPI factors presented the following Omega coefficients (McDonald, 1999): AC $(\omega=.93), \mathrm{AF}(\omega=.91)$ and $\mathrm{A}(\omega=.85)$.

ReducedPersonalityMarkers Scale(RPMS)(HauckFilho, Machado, Teixeira, Bandeira, 2012). Instrument composed of 25 items that assess personality based on the Big Five model: neuroticism $(\mathrm{N})$, extroversion $(\mathrm{E})$, socialization $(\mathrm{S})$, conscientiousness $(\mathrm{C})$, and openness to experience $(\mathrm{OE})$. The RPMS factors presented the following Omega coefficients (McDonald, 1999): $\mathrm{N}(\omega=.77), \mathrm{E}(\omega=.77), \mathrm{S}(\omega=.73)$, $\mathrm{C}(\omega=.73)$ and $\mathrm{OE}(\omega=.61)$.

\section{Procedure}

Data collection. The participants were recruited through social networks, using the snowball technique (Patton, 1990), where they referred the research to their peers. We included heterosexual Brazilians of both genders and over the age of 18 . The exclusion of non-heterosexual individuals is due to the fact that studies on CM carried out with these groups (Blake et al., 2017; van Houten, Tornello, Hoffenaar, \& Bos, 2020) indicate the need to include and problematize a set of individual and contextual variables, which address concerns unique to their sexual minority status, that were not considered in this study. Data was collected virtually via the online platform Surveymonkey, between December 2018 and July 2019.

Data analysis. The results were analyzed in SPSS for Windows version 23. The treatment of missing values followed the pairwise deletion method, excluding the data that did not have complete answers during the association with two variables. The normality of the distribution of each variable was analyzed by the Kolmogorov-Smirnov test, which identified that the variables had a non-normal distribution $(p<.000)$. The skewness and shortness indices for PCM were 6.70 and 6.41, respectively, and for NCM were 5.29 and 3.36. For this reason, we chose to use nonparametric tests in the analysis of correlation and differences between groups.

Spearman correlations were conducted between PCM and NCM and the following variables: sociodemographic (i.e., age, education, and income), childhood-related (i.e., number of siblings, birth order, and family support), 
personal characteristics (i.e., positivity, personality, and religiosity), and relationship with partner (i.e., dyadic consensus). Mann-Whitney and Kruskal Wallis U-tests were performed to evaluate group differences according to sex, occupation, presence/absence of partner, marital status, sibling care, and having or not having children. As a measure of effect size, the probability of superiority (PSest) calculation was performed and the following interpretative norms were used: no effect (PSest $\leq .00$ ); small effect (PSest $\geq .56$ ); medium effect (PSest $\geq .64$ ) and large effect (PSest $\geq .71$ ) (Caycho, Ventura-León, \& Castillo-Blanco, 2016). Finally, two multiple regressions were performed using the Stepwise - Backward method (Field, 2017), aiming to understand which variables could be considered as predictors of PCM and NCM.

\section{Ethical Considerations}

All ethical issues were guaranteed, according to the guidelines of Resolution No. 510/2016 of the Ministry of Health. Its conduct was authorized by the Ethics and Research
Chamber of the Centro de Filosofia e Ciências Humanas of the Universidade Federal do Rio de Janeiro (UFRJ) (CAAE No. 03490118.8.0000.5582 and Protocol No. 3.095.859). On the first page of the online questionnaire, there was the Free and Informed Consent Term (FICT), which presented information about the risks and benefits of answering the study, as well as the guarantee of withdrawal of consent, without prejudice and at any time. Only those participants who checked the consent option had access to the research content. Those who did not check the consent option were redirected to the end of the questionnaire.

\section{Results}

To investigate possible differences in PCM and NCM, according to the sociodemographic variables: sex, occupation, care of younger siblings, presence or absence of a partner, and having or not having children, comparisons between groups were made using the Mann-Whitney U test (Table 1).

Table 1

Group differences using the Mann-Whitney " $U$ ” test

\begin{tabular}{|c|c|c|c|c|c|c|c|}
\hline Scale & Mean & Minimum & Maximum & \multicolumn{2}{|c|}{ Minimum value of the scale } & \multicolumn{2}{|c|}{ Midpoint of the scale } \\
\hline PCM & 69.89 & 27 & 108 & \multicolumn{2}{|c|}{80} & \multicolumn{2}{|c|}{40} \\
\hline NCM & 57.67 & 20 & 80 & \multicolumn{2}{|c|}{108} & \multicolumn{2}{|c|}{54} \\
\hline Groups & & Mean range 1 & Mean range 2 & $U$ & $Z$ & Signif, $(p)$ & $P S_{\text {est }}$ \\
\hline $\begin{array}{l}\text { Sex: } \\
1=\text { male } \\
2=\text { female }\end{array}$ & $\begin{array}{l}\text { PCM } \\
\text { NCM }\end{array}$ & $\begin{array}{c}1008.45 \\
\mathbf{8 0 4 . 9 3}\end{array}$ & $\begin{array}{l}974.47 \\
\mathbf{9 3 0 . 8 4}\end{array}$ & $\begin{array}{l}252505.000 \\
\mathbf{1 9 3 2 8 5 . 5 0 0}\end{array}$ & $\begin{array}{l}-0.982 \\
\mathbf{- 3 . 7 6 3}\end{array}$ & $\begin{array}{l}.326 \\
.000\end{array}$ & $\begin{array}{l}.48 \\
.43\end{array}$ \\
\hline $\begin{array}{l}\text { Insertion in the job market } \\
1=\text { yes } \\
2=\text { no }\end{array}$ & $\begin{array}{l}\text { PCM } \\
\text { NCM }\end{array}$ & $\begin{array}{l}962.71 \\
907.14\end{array}$ & $\begin{array}{c}\mathbf{1 0 2 1 . 8 3} \\
918.51\end{array}$ & $\begin{array}{l}\mathbf{3 7 3 1 2 1 . 5 0 0} \\
340547.500\end{array}$ & $\begin{array}{l}\mathbf{- 2 . 1 0 5} \\
-0.421\end{array}$ & $\begin{array}{l}.035 \\
.673\end{array}$ & $\begin{array}{l}.47 \\
.49\end{array}$ \\
\hline $\begin{array}{l}\text { Caring for Younger Siblings } \\
1=\text { yes } \\
2=\text { no }\end{array}$ & $\begin{array}{l}\text { PCM } \\
\text { NCM }\end{array}$ & $\begin{array}{l}866.67 \\
801.51\end{array}$ & $\begin{array}{l}847.51 \\
786.43\end{array}$ & $\begin{array}{l}318957.500 \\
273975.500\end{array}$ & $\begin{array}{l}-0.760 \\
-0.620\end{array}$ & $\begin{array}{l}.447 \\
.535\end{array}$ & $\begin{array}{l}.49 \\
.49\end{array}$ \\
\hline $\begin{array}{l}\text { Have children } \\
1=\text { yes } \\
2=\text { no }\end{array}$ & $\begin{array}{l}\text { PCM } \\
\text { NCM }\end{array}$ & $\begin{array}{c}1357.51 \\
655.07\end{array}$ & $\begin{array}{l}936.60 \\
938.19\end{array}$ & $\begin{array}{l}101199.500 \\
100671.500\end{array}$ & $\begin{array}{c}-10.017 \\
-6.829\end{array}$ & $\begin{array}{l}.000 \\
.000\end{array}$ & $\begin{array}{l}.29 \\
.34\end{array}$ \\
\hline $\begin{array}{l}\text { Presence } / \text { absence of partner } \\
1=\text { yes } \\
2=\text { no }\end{array}$ & $\begin{array}{l}\text { PCM } \\
\text { NCM }\end{array}$ & $\begin{array}{l}\mathbf{9 9 7 . 0 8} \\
912.64\end{array}$ & $\begin{array}{l}\mathbf{8 8 5 . 2 0} \\
897.78\end{array}$ & $\begin{array}{l}\mathbf{2 1 9 8 2 4 . 0 0 0} \\
200765.500\end{array}$ & $\begin{array}{l}-\mathbf{3 . 1 4 9} \\
-0.424\end{array}$ & $\begin{array}{l}.002 \\
.672\end{array}$ & $\begin{array}{l}.44 \\
.49\end{array}$ \\
\hline
\end{tabular}

Note. $\mathrm{PCM}=$ Motivation for positive childbearing; NCM = Motivation for negative childbearing; Mann-Whitney "U"; PSest = Probability of superiority index.

Statistically significant differences with small effect sizes were found in PCM in three categories tested: occupation $\left(U=373121.500 ; p=.035 ; P S_{\text {est }}=.47\right)$, presence/absence of partner $\left(U=101199.500 ; p=.000 ; P S_{\text {est }}=.29\right)$ and presence/absence of children $(U=219824.000 ; p=.002$; $\left.P S_{\text {est }}=.44\right)$. It was observed that the participants who were unemployed $(M d n=1021.83)$, who had one or more children $(M d n=1357.51)$ and who were in a relationship $(M d n=997.08)$; had significantly higher levels of PCM than people who worked $(M d n=962.71)$, who had no children $(M d n=936.60)$ and who did not have a relationship $(M d n=885.20)$.
On the other hand, NCM indicated statistically significant differences with small effect sizes related to sex $\left(U=193285.500 ; p=.000 ; P S_{\text {est }}=.43\right)$ and the presence/ absence of children $\left(U=100671.500 ; p=.000 ; P S_{\text {est }}=.34\right)$. It was observed that both women $(M d n=930.84)$ as for the participants who do not have children $(M d n=938.19)$ have significantly higher levels of NCM than men $(M d n=804.93)$ and participants with children $(M d n=655.07)$.

Based on the results obtained in the comparison between people who are or are not in a stable relationship, we tested the possible differences in PCM according to the type 
of relationship using the Kruskal Wallis test. The results showed levels of PCM significantly influenced by the type of relationship $(H(2)=29.339 ; p=.000)$. Mann-Whitney tests were used to follow up on this finding. A Bonferroni correction was applied and all effects were tested at the .02 level. PCM levels showed no differences between people who were dating and people who were married or in a stable union $\left(U=290045.000 ; p=.039 ; P S_{\text {est }}=.47\right)$. However, statistically significant differences were found in PCM levels between married and in a stable union $(U=53556.000$; $\left.p=.000 ; P S_{\text {est }}=.41\right)$, of which married people $(M d n=514.93)$ had higher levels of PCM when compared to people who were in a stable union $(M d n=430.04)$.
Two Spearman correlations were conducted. In the first, the relationship between PCM and NCM was evaluated and it was found that PCM $(M=69.89$; $D P=20.50)$ correlates negatively with the NCM $(M=57.29$; $D P=13.78) ; p=.000 ; r=-.494 ; r^{2}=.24$. In the second analysis the relationships between PCM, NCM and 16 individual and contextual variables were tested and can be seen in Table 2. Weak associations were found both positive and negative between PCM or NCM and 12 of the variables tested. Specifically the sociodemographic variables: "number of siblings" and "birth order" and the personality factors: "conscientiousness" and "openness to experience" showed no significant correlations with PCM and NCM.

Table 2

Spearman's correlations between PCM, NCM and other variables

\begin{tabular}{|c|c|c|}
\hline Variable & $\mathrm{PCN}$ & $\mathrm{NCM}$ \\
\hline Age & $-.087 * *$ & $.049 *$ \\
\hline Education & $-.083 * *$ & .009 \\
\hline Income & $.046 *$ & -.030 \\
\hline Number of siblings & .000 & -.019 \\
\hline Order in birth & -.006 & -.044 \\
\hline Positivity & $.130 * *$ & $-.147 * *$ \\
\hline Religiosity & $.359 * *$ & $-.156 * *$ \\
\hline Dyadic consensus & $.050 *$ & -.021 \\
\hline Extroversion (Personality) & .011 & $-.063 *$ \\
\hline Conscientiousness (Personality) & .039 & -.030 \\
\hline Neuroticism (Personality) & $-.057 *$ & $.130 * *$ \\
\hline Socialization (Personality) & $.128 * *$ & $-.119 * *$ \\
\hline Openness to experience (Personality) & -.049 & .011 \\
\hline Consistent Affective (Family Support) & $.254 * *$ & $-.173 * *$ \\
\hline Family Adaptation (Family Support) & $.186 * *$ & $-.167 * *$ \\
\hline Family Autonomy (Family Support) & $.079 * *$ & -.043 \\
\hline
\end{tabular}

Note. $\mathrm{PCM}=$ Motivation for positive childbearing; $\mathrm{NCM}=$ Motivation for negative childbearing; $* *$ Significant correlation at $p<.01$ level; $* *$ Significant correlation at $p<.05$ level.

Considering the correlations found, two multiple regressions were performed to understand which variables could be considered as predictor variables of PCM and NCM in the present sample (Table 3).

The models presented in Table 3 were statistically significant and explained $24 \%$ of the total variance of PCM and 10\% of NCM. Eight of the 14 variables analyzed presented themselves as significant predictors of PCM.
The variables: religiosity, having or not having children, and age showed stronger relationships with PCM, obtaining coefficients of $\beta=.32, \beta=-.22$ and $\beta=.17$, respectively. Regarding the NCM, only four of the 12 variables surveyed presented themselves as predictor variables. The variables having or not having children $(\beta=.17)$, age $(\beta=.14)$, religiosity $(\beta=-.12)$ and $\operatorname{sex}(\beta=.10)$ exhibited stronger relationships with the NCM. 
Table 3

Multiple linear regression for PCM and NCM

\begin{tabular}{|c|c|c|c|c|c|c|}
\hline & Model Variable & $B$ & Standard error of the coefficient & $\beta$ & $\mathrm{T}$ & Statistical significance \\
\hline \multirow{16}{*}{ PCM } & Sex & -4.228 & 1.318 & -.077 & -3.208 & .001 \\
\hline & Age & -0.549 & 0.093 & -.172 & -5.905 & .000 \\
\hline & Education & -0.665 & 0.438 & -.042 & -1.518 & .129 \\
\hline & Income & 1.461 & 0.352 & .105 & 4.153 & .000 \\
\hline & $\begin{array}{l}\text { Have or do not have } \\
\text { children }\end{array}$ & -14.618 & 1.678 & -.215 & -8.709 & .000 \\
\hline & Work & 1.189 & 1.162 & .027 & 1.023 & .307 \\
\hline & Neuroticism & 0.402 & 0.152 & .078 & 2.641 & .008 \\
\hline & Socialization & 0.322 & 0.196 & .040 & 1.643 & .101 \\
\hline & Religiosity & 0.474 & 0.036 & .323 & 13.077 & .000 \\
\hline & Positivity & 0.128 & 0.111 & .036 & 1.154 & .249 \\
\hline & Dyadic consensus & 0.050 & 0.060 & .021 & 0.836 & .403 \\
\hline & Couple & -3.355 & 1.574 & -.052 & -2.131 & .033 \\
\hline & Affective-consistent & 0.235 & 0.072 & .113 & 3.246 & .001 \\
\hline & Family adjustment & 0.221 & 0.121 & .066 & 1.822 & .069 \\
\hline & Family autonomy & -0.036 & 0.167 & -.006 & -0.217 & .828 \\
\hline & $R=.491 ; R^{2}=.241 ; R$ & usted $=.2$ & & & & \\
\hline \multirow{12}{*}{$\mathrm{NCM}$} & Sex & 3.628 & 0.955 & .098 & 3.801 & .000 \\
\hline & Age & 0.306 & 0.062 & .141 & 4.945 & .000 \\
\hline & Work & 0.283 & 0.826 & .009 & 0.343 & .732 \\
\hline & $\begin{array}{l}\text { Have or do not have } \\
\text { children }\end{array}$ & 8.026 & 1.224 & .172 & 6.556 & .000 \\
\hline & Neuroticism & 0.196 & 0.114 & .056 & 1.722 & .085 \\
\hline & Socialization & -0.233 & 0.143 & -.043 & -1.622 & .105 \\
\hline & Extroversion & 0.029 & 0.089 & .009 & 0.327 & .744 \\
\hline & Religiosity & -0.120 & 0.026 & -.120 & -4.555 & .000 \\
\hline & Positivity & -0.139 & 0.081 & -.058 & -1.702 & .089 \\
\hline & Couple & -0.694 & 1.110 & -.016 & -0.625 & .532 \\
\hline & Affective-consistent & -0.067 & 0.053 & -.047 & -1.271 & .204 \\
\hline & Family adjustment & -0.126 & 0.085 & -.055 & -1.487 & .137 \\
\hline
\end{tabular}

Note. $\mathrm{PCM}=$ Motivation for positive childbearing; $\mathrm{NCM}=$ Motivation for negative childbearing.

\section{Discussion}

Correlations were found between PCM, NCM and the 12 variables tested; furthermore, eight variables were found to be predictors of PCM and four were predictors of NCM, corroborating Miller's proposition that describes $\mathrm{CM}$ as constructs that are influenced by multiple individual and contextual variables (Miller, Pasta, MacMurray, Muhleman, \& Comings, 2000).

The independence between PCM and NCM found by both Miller and other researchers (Mynarska \& Rytel, 2018, 2020), was not found in this research. The results indicate a moderate negative relationship between both constructs; therefore, higher levels of PCM are associated with lower levels of
NCM and vice-versa. When considering these findings, it is important to take into account the characteristics of the present sample, which was composed mostly of young women ( $M=29$ years), with an education level equal to or higher than complete undergraduate studies and who are inserted in the labor market. This profile differs from the samples of studies carried out in other contexts. Thus, the hypothesis for the correlation found is that there is ambivalence about the PCM and the NCM in women with high levels of education and inserted in the labor market due to the difficulties to reconcile professional and family life. If before there was social pressure for women to stay out of the labor market, especially after the birth of their children, currently the reality is the opposite and the demand for women to engage in some paid activity 
is as high as for men (Caldwell, 2018), although they are still the main responsible for domestic and care activities within families (Esping-Andersen \& Billari, 2015). Therefore, in the social landscape where diverse roles overlap, the motivations for childbearing are forces that act simultaneously on women. We emphasize that the presented hypothesis should be tested by other researches with samples with diversified sociodemographic characteristics.

The analyses on the differences between groups showed that the variable having or not having children is the only one that shows differences in both PCM and NCM levels. People who have children had higher levels of PCM and lower levels of NCM when compared to people who do not have children. Differences in CM in people with and without children have been found in other studies (Irani \& Khadivzadeh, 2019; Miller, 1994; Miller \& Pasta, 1995). Miller and Pasta (1993), pointing out that CM may vary according to the number of children you have, depending on the positive or negative evaluation of the previous childbearing experience and personal and contextual factors that would favor, or hinder the exercise of a new childbearing process (Miranda-Ribeiro et al., 2019).

On the other hand, the variables: occupation, presence/ absence of partner and type of relationship, present differences in the levels of PCM. It was found that people who were in the labor market and who have a relationship showed higher levels of PCM. These differences were also discovered according to the type of relationship. People who were married or living in a stable union did not show higher levels of PCM than those who were dating, however, when comparing married and stable union people, the former showed higher levels of PCM than the latter. This finding indicates that the levels of PCM in the sample are not only associated with the fact of having a partner, but also the social, legal, or religious formality of the relationship, which can convey a sense of security and stability necessary for reproductive decision making. Studies have shown that the official status of the relationship is one of the variables that most differs between women who have had children and women who have not had children in Brazil, showing that among people who have had children, married or in a stable union predominate, while among people who have not had children, single women predominate (Caetano et al., 2016). Although marital status is an important factor in PCM and NCM, this condition seems to have less relevance over the decades for younger individuals (Oliveira \& Marcondes, 2016).

Considering that sexual reproduction requires the combined action of two individuals, Miller (1994) made explicit the importance of the partner as an influencing factor in CM. The author presented the dyadic level, in which each individual component of the T-D-I-B model interacts with the partner component (Miller et al., 2004). A study conducted by Varas and Borsa (2019) in Peruvian men and women, also evidenced higher levels of PCM among people with a partner compared to those who were not in a relationship.

The comparison of PCM levels between unemployed people and people who have paid jobs showed lower levels of this construct among the former. Mills and Blossfeld (2005) exposed that under conditions of economic uncertainty, including low wages or unemployment; people tend to postpone long-term binding commitments that require a secure economic basis, such as having children; due to the assessment of the negative impact of childbearing under these conditions. It is important to mention that labor market participation is an unstable variable over the life course, since multiple entries and exits from the labor market may occur for personal reasons or superseded by the economic situation of the country at the time of job search (Smeha \& Calvano, 2009).

On the other hand, women presented higher levels of NCM than men, corroborating findings of studies conducted in other contexts (Alexander et al., 2019; Mynarska \& Rytel, 2020). With women's access to education, insertion in the labor market and the reduced participation of men in domestic activities, educational practices and parenting tasks, women presented greater difficulties in reconciling family and professional life, which makes it understandable that the negative aspects of motherhood are more heavily weighted (Miranda-Ribeiro et al., 2019).

The correlations found point to the influence of multiple individual and contextual variables on CM (Miller, 1994, 1995; Miller \& Pasta, 1993; Miller et al., 2000, 2004). The results in the regressions indicated a percentage of variance explained for PCM equal to $24 \%$ and a percentage of variance explained for $\mathrm{NCM}$ equal to $13 \%$, suggesting the existence of other factors that influence both types of CM not considered in this study.

Religiosity was the variable with the highest predictive power of PCM and this result corroborates the findings of several studies (Ghazanfarpour et al., 2018; Miller \& Pasta, 1995). Considering that Brazil is currently the country with the largest number of Christians in the world, with $50 \%$ of the population being Catholic and 31\% Evangelical (Alves, Cavenaghi, Barros, \& Carvalho, 2017), the relationship between religiosity and PCM becomes an important variable to be analyzed. Religious practice is related to the transmission of family-centered values (Miller \& Pasta, 1995), which emphasizes reproduction as the main goal of family formation, which may explain the predictive power of this variable in PCM, highlighting positive aspects of childbearing (Pearce \& Davis, 2016).

The variables having or not having children and age were presented as predictor variables for both PCM and NCM, corroborating the results of other studies (Irani \& Khadivzadeh, 2019; Miller \& Pasta, 1995; Mynarska \& Rytel, 2020). The variable not having children showed greater predictive power for NCM. This result indicates adequacy to that found in the analysis of difference between groups in the present study, whose group that did not have children showed higher levels of NCM than the one with children. On the other hand, these results do not corroborate the findings of other studies regarding women with children, which showed higher levels of NCM than women without children (Irani \& Khadivzadeh, 2019; Mynarska \& Rytel, 2020). These studies explained that the results pointed to the fact that women with children had a clearer idea of the physical, economic 
and emotional costs of childbearing, unlike a person who does not have children and who romanticizes motherhood. This difference between the results requires careful analysis, since our sample was predominantly made up of women with higher levels of education, income, and who are in the labor market than the population average; these characteristics may facilitate negative evaluations about childbearing, considering the real costs they would have due to their current professional activities. It should be noted that this is a hypothesis and requires studies with more homogeneous samples so that this hypothesis can be corroborated or refuted.

The results related to the impact on $\mathrm{CM}$ in relation to the variable age show that older people have lower levels of PCM and higher levels of NCM. These findings should also be reflected, considering the characteristics of the sample, which was composed mostly of people with high levels of education and income, as well as being inserted in the labor market; whose increased age may be associated with a possible increase in professional responsibilities and greater difficulty in reconciling work and family life (Caetano et al., 2016). Such a hypothesis may justify a marked evaluation on the negative aspects of childbearing and attenuation on the positive aspects.

The main contribution of this study refers to the pioneering analysis of the predictive factors on the motivations for childbearing in Brazil, presenting evidence on the influences of contextual and personal variables on parental motivations. These findings raise reflections on the importance of identifying the impact of these factors in order to contribute to the development of interventions appropriate to each reality to achieve people's reproductive goals. It is also hoped that these data foster reflections on public policies aimed at reproductive decision-making and the free exercise of sexuality, with autonomy, responsibility and safety.

The limitations of the present study are related to the restrictions of a cross-sectional study that does not allow us to verify the evaluation of $\mathrm{CM}$ over time. It can also be considered a limitation the sociodemographic profile of the participants (i.e., predominantly women, with high income and high education level), which differs from the majority of the Brazilian population. We also consider it important to mention the need for caution in interpreting the results due to the weak correlations and low Beta parameters in the regression analysis. However, it is expected that the limitations of this study will be a motivating factor for the development of new Brazilian research to seek relationships with other variables and with more diversified samples, aiming to expand the scientific knowledge about this construct.

\section{Referências}

Alexander, K. A., Perrin, N., Jennings, J. M., Ellen, J., \& Trent, M. (2019). Childbearing motivations and desires, fertility beliefs, and contraceptive use among urban African-American adolescents and young adults with STI histories. Journal of Urban Health, 96(2), 171-180. doi:10.1007/s11524-018-0282-2
Alves, J. E., Cavenaghi, S. M., Barros, L. F. W., \& Carvalho, A. A. (2017). Distribuição espacial da transição religiosa no Brasil [Spatial distribution of the Brazilian religious transition]. Tempo Social, 29(2), 215-242. doi:10.11606/0103-2070.ts.2017.112180

Baptista, M. N. (2005). Desenvolvimento do Inventario de Percepção de Suporte Familiar (IPSF): Estudos psicométricos preliminares [Development of Inventário de Percepção de Suporte Familiar (IPSF): Preliminary psychometrics studies]. Psico-USF, 10(1), 11-19. doi:10.1590/S1413-82712005000100003

Blake, L., Carone, N., Raffanello, E., Slutsky, J., Ehrhardt, A. A., \& Golombok, S. (2017). Gay fathers' motivations for and feelings about surrogacy as a path to parenthood. Human Reproduction, 32(4), 860-867. doi:10.1093/ humrep/dex026

Borsa, J. C., Damásio, B. F., Souza, D. S., Koller, S. H., \& Caprara, G. V. (2013). Psychometric properties of the positivity scale - Brazilian version. Psicologia: Reflexão e Crítica, 28(1), 61-67. doi:10.1590/ 1678-7153.201528107

Caetano, C., Martins, M. S., \& Motta, R. C. (2016). Família contemporânea: Estudo de casais sem filhos por opção [Contemporary family: Study of couples without children by option]. Pensando Famílias, 20(1), 43-56. http:// pepsic.bvsalud.org/pdf/penf/v20n1/v20n1a04.pdf

Caprara, G. V., Alessandri, G., Trommsdorff, G., Heikamp, T., Yamaguchi, S., \& Suzuki, F. (2012). Positive orientation across three cultures. Journal of Cross-Cultural Psychology, 43(1), 77-83. doi: $10.1177 / 0022022111422257$

Caldwell, J. C. (2018). Three fertility compromises and two transitions. Population Research and Policy Review, 27(4), 427-446. doi:10.1007/s11113-008-9071-z

Caycho, T., Ventura-León, J., \& Castillo-Blanco, R. (2016). Magnitud del efecto para la diferencia de dos grupos en ciencias de la salud [Effect size for the difference of two groups in health sciences]. Anales del Sistema Sanitario de Navarra, 39(3), 459-461. http://scielo.isciii.es/pdf/ asisna/v39n3/carta2.pdf

Esping-Andersen, G., \& Billari, F. C. (2015). Retheorizing family demographics. Population and Development Review, 41(1), 1-31. doi:10.1111/ j.1728-4457.2015.00024.x

Field, A. (2017). Discovering statistics using IBM SPSS statistics. London, United Kingdom: Sage.

Fundo de População das Nações Unidas. (2018). O poder de escolha. Direitos reprodutivos e transição demográfica [The power of choice. Reproductive rights and demographic transition]. https://brazil.unfpa.org/sites/ default/files/pub-pdf/SWOP_2018.pdf 
Ghazanfarpour, M., Arghavani, E., Khadivzadeh, T., Saeidi, M., Kareshki, H., Heidari, E., \& Rajab Dizavandi, F. (2018). Childbearing motivation in Iranian engaged couples: A structural equation model. International Journal of Pediatrics, 6(4), 7563-7568. doi:10.22038/ IJP.2018.27375.2359

Hauck Filho, N., Machado, W. L., Teixeira, M. A. P., \& Bandeira, D. R. (2012). Evidências de validade de marcadores reduzidos de personalidade no modelo dos cinco grandes fatores [Validity evidences of mini-markers for assessing the big five personality model]. Psicologia: Teoria e Pesquisa, 28(4), 417-423. doi:10.1590/S010237722012000400007

Hernández, J. A. E. (2008). Avaliação estrutural da escala de Ajustamento Diádico [Structural Assessment of the Diadyc Adjustment Scale]. Psicologia em Estudo, 13(3), 593-601. doi:10.1590/S1413-73722008000300021

Irani, M., \& Khadivzadeh, T. (2019). The relationship between childbearing motivations with fertility preferences and actual child number in reproductiveage women in Mashhad, Iran. Journal of Education and Health Promotion, 7, 175. doi:10.4103/jehp.jehp_175_18

Martine, G. (1996). Brazil's fertility decline, 1965-95: A fresh look at key factors. Population and Development Review, 22(1), 47-75. doi:10.2307/2137686

McDonald, R. P. (1999). Test theory: A unified treatment. New York, NY: Routledge.

Miller, W. B. (1992). Personality traits and developmental experiences as antecedents of childbearing motivation. Demography, 29(2), 265-285. doi:10.2307/2061731

Miller, W. B. (1994). Childbearing motivations, desires, and intentions: A theoretical framework. Genetic, Social and General Psychology Monographs, 120(2), 223-258.

Miller, W. B. (1995). Childbearing motivations and its measurement.JournalofBiosocialScience, 27(4),473-487. doi:10.1017/s0021932000023087

Miller, W. B., \& Pasta, D. J. (1993). Motivational and nonmotivational determinants of child-number desires. Population and Environment, 15(2), 113-138. doi: 10.1007/BF02209405

Miller, W. B., \& Pasta, D. J. (1995). Behavioral intentions: Which ones predict fertility behavior in married couples? Journal of Applied Social Psychology, 25(6), 530-555. doi:10.1111/j.1559-1816.1995.tb01766.x

Miller, W. B., Pasta, D. J., MacMurray, J., Muhleman, D., \& Comings, D. E. (2000). Genetic influences on childbearing motivation: Further testing a theoretical framework. In J. L. Rodgers, D. C. Rowe, \& W. B. Miller (Eds.), Genetic influences on human fertility and sexuality (pp. 35-66). Boston, MA: Springer.
Miller, W. B., Severy, L. J., \& Pasta, D. J. (2004). A framework for modelling fertility motivation in couples. Population Studies, 58(2), 193-205. doi:10.1080/0032472042000213712

Mills, M., \& Blossfeld, H.-P. (2005). Globalization, uncertainty and the early life course: A theoretical framework. In H.-P. Blossfeld, E. Klijzing, M. Mills, \& K. Kurz (Eds.), Globalization, uncertainty and youth in society (pp. 1-24). London: Routledge.

Miranda-Ribeiro, A., Garcia, R. A., \& Faria, T. C. A. B. (2019). Baixa fecundidade e adiamento do primeiro filho no Brasil [Low fertility and postponement of first birth in Brazil]. Revista Brasileira de Estudos de População, 36, e0080. doi:10.20947/s0102-3098a0080

Mynarska, M., \& Rytel, J. (2018). From motives through desires to intentions: Investigating the reproductive choices of childless men and women in Poland. Journal of Biosocial Science, 50(3), 421-433. doi:10.1017/ S0021932017000190

Mynarska, M., \& Rytel, J. (2020). Fertility desires of childless poles: Which childbearing motives matter for men and women? Journal of Family Issues, 41(1), 7-32. doi:10.1177/0192513X19868257

Oliveira, M. C. F. A., \& Marcondes, G. S. (2016). Os tempos para o trabalho e para a família na população feminina em áreas metropolitanas brasileiras [Times for work and family in the female population in Brazilian metropolitan areas]. Idéias, 7(1), 61-88. doi:10.20396/ ideias.v7i1.8649511

Patton, M.Q. (1990) Qualitative evaluation and research methods. London: Sage Publications.

Pearce, L. D., \& Davis, S. N. (2016). How early life religious exposure relates to the timing of first birth. Journal of Marriage and Family, 78(5), 1422-1438. doi:10.1111/ jomf. 12364

Rios-Neto, E. L. G., Miranda-Ribeiro, A., \& MirandaRibeiro, P. (2018). Fertility differentials by education in Brazil: From the conclusion of fertility to the onset of postponement transition. Population and Development Review, 44(3), 489-517. doi:10.1111/padr.12165

Smeha, L., \& Calvano, L. (2009). O que completa uma mulher? Um estudo sobre a relação entre não-maternidade e vida profissional [What completes a woman? A study about the relation between non-maternity and professional life]. Psicologia Argumento, 27(58), 207-217. https:// periodicos.pucpr.br/index.php/psicologiaargumento/ article/view/19849

Spanier, G. B. (1976). Measuring dyadic adjustment: New scales for assessing the quality of marriage and similar dyads. Journal of Marriage and the Family, 38(1), 15-28. doi: $10.2307 / 350547$ 
Tavares, L. P. (2016). Who delays childbearing? The associations between time to first birth, personality traits and education. European Journal of Population, 32(4), 575-597. doi:10.1007/s10680-016-9393-1

van Houten, J. T., Tornello, S. L., Hoffenaar, P. J., \& Bos, H. M. W. (2020). Understanding parenting intentions among childfree gay men: A comparison with lesbian women and heterosexual men and women. Frontiers in Psychology, 11, 430. doi:10.3389/fpsyg.2020.00430

Varas, G. V., \& Borsa, J. C. (2019). Revisión sistemática del estudio de las motivaciones para la parentalidad [Systematic review of motivation to parenthood studies]. Estudos \& Pesquisas em Psicologia, 19(1), 261-283. doi:10.12957/epp.2019.43019

Giuliana Violeta Vasquez Varas is a Ph.D. candidate of the Faculdade de Psicologia at Pontifícia Universidade Católica do Rio de Janeiro.

Juliane Callegaro Borsa is a Professor of the Faculdade de Psicologia at Pontifícia Universidade Católica do Rio de Janeiro.

Authors' Contribution:

All authors made substantial contributions to the conception and design of this study, to data analysis and interpretation, and to the manuscript revision and approval of the final version. All the authors assume public responsibility for content of the manuscript.

Associate editor:

Eduardo Name Risk

Received: Sep. 10, 2020

1st Revision: Nov. 13, 2020

2nd Revision: Jan. 26, 2021

Approved: Feb. 12, 2021

How to cite this article:

Varas, G. V., \& Borsa, J. C. (2021). Predictor variables of childbearing motivations in Brazilian women and men. Paidéia (Ribeirão Preto), 31, e3112. doi: https://doi.org/10.1590/1982-4327e3112 